\title{
Determinants of interest free financial products in Ethiopian banking industry
}

\author{
Debebe Alemu Kebede
}

Department of Management, Jimma University, Ethiopia

Correspondence author email: debealex2@gmail.com

\begin{tabular}{|l|l|l|l|l|}
\hline DOI: & Received: & Revised: & Accepted: & Published: \\
$10.22437 /$ ppd.v8i3.9241 & 07.05 .2020 & 12.08 .2020 & 15.08 .2020 & 31.08 .2020 \\
\hline
\end{tabular}

\begin{abstract}
This study is undertaken to identify the determinants of the use and adoption of Interest free financial products in Ethiopian banking industry with specific reference to commercial banks. To achieve the aim of the study the primary data was collected from managers of some selected commercial banks through un-structured interview as well as from customers by using convenience method through standard questionnaires. While, secondary data was collected from documents of banks and Journals to triangulate with response obtained from primary data sources. The collected data was analyzed in descriptive and inferential analysis. The findings depicted as the Economic factors like unemployment and saving habits affecting the adoption of Interest free financial products and services by banks. Further, the obsoleting of technological environment, Inflexibility of government policies, Educational background of the customers and diverse cultures of the societies are the other factors that affecting adoption of financial products. In addition, the Interest free financial products and services are not properly used by the customers as the result of their low level of awareness, the perceived relative advantage, perceived compatibility and perceived complexity and perceived trust of existing banking system. Based on the result it is recommended as the banks should properly adopt the Interest free financial products and services with taking into account of the external factors. Further, the banks should participate on aggressive promotion to aware the customers about their Interest free products and services, the government should formulate policies and regulations that minimizing bureaucracy of adopting technology by banks.
\end{abstract}

Keywords: Commercial banks, Ethiopia, Financial product, Interest free

JEL Classification: G20,O36

\section{INTRODUCTION}

The introduction serves two purposes: to stimulate the reader's interest and to outline the reason for the study, that is, the controversy or 'knowledge gap' that prompted the study. State the objectives of the work and provide an adequate background. One of the most emerging trends in the global economies is the idea of Interest free banking and Finance (Ahmad, 2000), that emerged in the global landscape as an alternative banking system which is in line with values and ethos of Islam, and governed by the principles of Sharia Law that requires not charge interest and avoid any unethical practices in achieving its goals and objectives (Gait \& Worthington, 2008). This form of interest-free banking 
has developed over a long period of time in Egypt in 1963 with the introduction of new products in the industry. The role and functions of Islamic banking within the banking system in a modern economy are very important, and in fact, it is at the heart of every robust economy. Hence, Islamic banking is growing at an average rate of 15 per cent a year in size and number, which makes it the fastest-growing sector in the financial markets of the contemporary world (Saidi, 2007; B.S. \& Ming-Hua, 2007).

While, the global Islamic banking and finance industry assets worth at over USD1.3 trillion in 2012 and expected to reach USD 2 trillion in next three to five years. The breakthrough in banking industry is occasioned by the introduction and growth of the Interest free banking. However, despite the growth in Islamic banking, there are concerns that development of Islamic banking remains somewhat limited and that the industry may be suffering from a lack of innovation (Khan \& Bhatti, 2008b) and lack of initiatives in convincing customers that they are really offering Shariah compliant products and not dressing up conventional banking practices (Karbhari, Naser, \& Shahin, 2004).

Despite the growth of Islamic banking worldwide, as the others African countries Ethiopian banking industry was continued to conduct most of their banking transactions using traditional banking system because of lack of supportive regulatory and policy regimes that facilitate the establishment of Islamic financial institutions is the most important worth of mentioning. Since, Muslims believe that banking with the conventional banks is against their religious faith; large numbers of potential Muslim customers are not banking with the existing conventional banks available in the country. To satisfy the community that have problem with the current banking system and to provide alternative banking system the National Bank of Ethiopia (NBE)was expected to approve a directive that paves the way for the establishment of what was called as the first Islamic bank in Ethiopia. A circulated draft form of the $\mathrm{NBE}^{\text {ee }} \mathrm{s}$ directive has allowed Ethiopian nationals to establish a bank exclusively engaged in interest- free banking," however, that hope was short living one as the finally issued draft does not allow the establishment of full-fledged Islamic financial institution.

However, the directive has only opened the door for "existing commercial banks ${ }^{\text {ee }}$ to create an interest-free banking window alongside of their operations. This Come in to force in October 2011, but interest-free banking in Ethiopia started only in September 2013, when the Oromia International Bank S.C launched the service. The Commercial Bank of Ethiopia joined the market at the end of October, followed by United bank S.C, which began providing the service on May 1, 2014. The introduction of interest-free banking in Ethiopian banking industry is important for being a world class bank, and in addition to provide options for the customers.

For Interest free (Islamic) banking to continue this expansion and succeed in any other setting, it has to be accepted and positively perceived by the potential customers. These makes Customers ${ }^{\text {ee }}$ intention has become an enduring research topic in banking (Holliday, 1996). Due to higher demand, research should be conducted to check updates on customer's intention and satisfaction of Interest free (Islamic) banking product and services. Additionally, the factors that affecting the banking industry to adopt interestfree banking have been at the forefront of several research works in the developed and some developing world.

Nevertheless, there is very much limited published works that investigate the factors influencing the use of interest-free banking from the viewpoint of customers and banks in the context of developing countries like Ethiopia. To date there have been very few such studies, a remarkable exception to this is the study conducted by (Muhumed, 2012; Sankaramuthukumar \& Devamohan, 2008; Kebede, 2015; Shaik Abdul Majeeb, 2014) who studied Islamic banking prospect, opportunities and challenges in Ethiopia, that studied the Role and Progress of Islamic Banking in India, Ethiopia and Rest 
of the World, The Potentiality of Islamic banking in Ethiopia and factors that affecting the use of interest free banking Ethiopia.

Moreover, interest-free banking is a new system in Ethiopia which needs a lot of effort and resources to be easily adopted by customers. As the document of some commercial banks in Ethiopia indicated there are financial products and services outdated without even compensated the costs of its adoption. Hence, in order to help banks, improve interest-free financial product and services adoption by their customers, it is necessary to identify factors that influence customers' perceptions toward product and service they provide. Because understanding and adapting to customer motivation and behavior is not an option but an absolute necessity for competitive survival (OwusuFrimpong,1999)

Accordingly, this study aims to identify determinants of interest-free banking adoption by Ethiopian banking industry and factors that affect the customers to use and levels of customer's satisfaction with existing banks services. Therefore, the purpose of this study is to identify the current status of interest-free banking in Ethiopian banking industry, as well as factors that affecting the adoption, use and satisfaction towards interest-free banking.

\section{RESEARCH HYPOTHESES}

\section{Hypotheses related to adoption interest-free financial products and services:}

H1: The existing economic situation of the country has significant influence on adoption of interest-free financial products and services in Ethiopian banking industry

$\mathrm{H} 2$ : Existing Technological change has significant influence on adoption of interest-free financial products and services in Ethiopian banking industry

H3: The country government policies have significant influence on adoption of interestfree financial products and services in Ethiopian banking industry

H4: The societal cultures have significant influence on adoption of interest-free financial products and services in Ethiopian banking industry

\section{Hypotheses related to usage of digital financial products and services:}

H5: The position of the banks on customers' awareness have significant influence on using of interest-free financial products and services in Ethiopian banking industry

H6: The customers' perceived relative advantage has significant influence on using of interest-free financial products and services in Ethiopian banking industry

H7: The customers' perceived compatibility has significant influence on using of interest-free financial products and services in Ethiopian banking industry

H8: The customers' perceived complexity has significant influence on using of interestfree financial products and services in Ethiopian banking industry

H9: The customers' perceived trust towards banks has significant influence on using of interest-free financial products and services in Ethiopian banking industry

\section{METHODS}

\section{Research design}

The purpose of this study is to identify the factors that hinders the use and adoption of interest-free financial products in Ethiopian banking industry through illustrating it from all commercial banks headquarters, a deductive and mixed research approach is well suited. Further, to achieve the objective of the study, the case study method will be applied. Case studies are in which the researcher explores in depth a program, and event, and activity, a process, or one or more individuals (Creswell, 2013). 


\section{Target population, sample size and sampling techniques}

The target population consists of the managers, Interest free window employees and customers. There are 19 commercial banks are there in Ethiopia all of its headquarters considered for the study. The minimum of 3 Interest free window employees and managers from each headquarters of banks (57) considered as sample. There are large number of customers consisted by those banks hence, according to (Hair \& R.E., 2006) a sample size between 200 and 400 is usually acceptable as critical sample size for attitudes studies. Therefore, 11 customers from each commercial bank (209 customers) considered as sample size by using convenience sampling techniques.

\section{Data collection methods}

The study the primary data would be collected through un- structured interviews with managers of commercial banks and close-ended structured questionnaire items through the adaptation and modification of instruments from previous studies in the area of adoption studies and usage of innovations with customers and Interest free window employees of the banks. For measuring this information, the Likert scale method was used to range of responses: strongly disagree, disagree, Neutral, Agree, and strongly agree, with a numeric value of $1-5$, respectively. Likert-scale is used to ask many people the same questions and examining their answers research questions (Neuman \& Kreuger, 2003). So that the researcher would use cross sectional survey in which independent and dependent variables are measured at the same point in time using a single questionnaire (Anol, 2012). The secondary data would be collected by extracting relevant and supportive data and information from the secondary data sources.

\section{Data presentation and analysis}

Descriptive analysis would use to achieve the first specific objectives, primary data that were collected through interviews, demographic characterized of respondents and mean of variables. Correlation analysis also used to determine the relationship of variables before regression taken and then multiple linear regression analysis would be used to determine the potential connection between independent variables of this study and the dependent variable of study. Regression analysis was used to identify impacts of variables. Accordingly, these multiple tests would be able to identify potential factors that have a significant impact on adoption and use of financial product and services.

\section{Factor analysis}

Factor analysis is a statistical tool/technique which is used to verify the factor structure of a set of observed variables/constructs. It is also used to tests whether a specified set of constructs is influencing responses in a predicted way (Brown, 2015). Factor analysis will allow us to test that there exists a good relationship between observed variables and their underlying latent constructs. So, to evaluate the construct validity of the factors, factor analysis has been performed. The first pre-test has been done by filling $\&$ checking the questionnaire by five commercial bank of Ethiopia managers, to improve the questions and replace any confusing \& difficult terms. The purpose of first pretest was also to see, if we have overlooked some important dimensions/elements. Factor analysis is used as a pre-test after collecting empirical data through pre-test questionnaires (full version), to test whether there is significant relationship between the factors to measure and choosing the right variable/questions for measuring an underlying factor.

A large sample size has been recommended by different researchers (DeCoster, 1998) to perform Factor Analysis, where the minimum sample size required is 150 (Hair \& R.E., 2006). Therefore, a total of 178 responses have been collected for performing the Factor analysis and it done with the help of SPSS 20.0 software, as a second pre-test to verify the conceptualization of the selected constructs/indicators for each factor. After performing Factor Analysis, unimportant and irrelevant questions have been 
excluded from the full version questionnaire to get a final version of questionnaire. Results from factor analysis have provided factor loadings for each variable (question) where factor loading above 0.70 and $\mathrm{KMO}$ above 0.50 is termed as acceptable so that each factor is explained more by its constructed variable (question) than by, (Voorhees $e t$ al., 2016).

Several variables have factor loading above than 0.70 and KMO above 0.50 that prove as best measure of the corresponding factor. Following this, variables/questions with factor loading above 0.70 are kept for final questionnaire.

\section{Validity and reliability}

Validity is the degree to which a measure accurately represents what it is supposed to. Cronbach's alpha is used as only one criterion for judging instruments or scales (George \& Mallery, 2003). As the current study uses multiple items in all variables, internal consistency analysis was carried out through Cronbach's alpha reliability tests. The results of the reliability analysis, one can conclude that the items are internal consistent. To find the reliability of the empirical data, consistency analysis has been done using SPSS. Consistency analysis is used to find the internal consistency of the observed data, and ranges from 0 to 1 .

Although the instruments developed by different researchers to measure the hypothesized factors and consumers' perception, has established good validity and reliability. Among the factors, the factor Level of customers Awareness about financial products and services has the highest ranking of Cronbach's alpha of 0.873 , followed by the factor perceived Trust with 0.853. The factor Perceived Complexity has the lowest ranking with 0.705 . As well as Government policies about financial products and services has the highest ranking of Cronbach's alpha of 0.931, followed by Economic factors with 0.862 . Hence, all variables are retained as the factors are found with good consistency.

\section{RESULTS AND DISCUSSIONS}

This section presents the analysis, discussion and inferences made on the basis of the responses obtained. All the data were coded and entered in to SPSS version 20.0 and inferences were made based on the statistical results. The research instrument used in the study was survey questionnaire. The location of the study was Addis Ababa city. The study population comprised the commercial banks' managers, employees and customers with $85 \%$ of response rate.

Table 1. Respondents' demographic variables.

\begin{tabular}{llrc}
\hline Background & Distribution & Frequency & Percentage \\
\hline Affiliation years & Less than 1 year & 44 & 25 \\
& 1-5 years & 107 & 60 \\
& 5-10 years & 14 & 8 \\
& Above 10 years & 13 & 7 \\
\hline Reason of associations & Saving & 112 & 63 \\
& Investment & 9 & 5 \\
& Borrowing \& sending & 28 & 16 \\
& All & 29 & 16 \\
\hline Educational level & Illiterate & 10 & 6 \\
& Grade 10 complete & 17 & 9 \\
& Diploma & 38 & 21 \\
& Bachelor degree & 87 & 49 \\
& Masters and Above & 26 & 15 \\
\hline Nature of income & Family income & 30 & 17 \\
& Self-employed/merchant & 61 & 34 \\
& Government/NGO & 70 & 39 \\
& Irregular income & 17 & 10 \\
\hline
\end{tabular}


As the Table 1 indicates that Majority of respondents $(60 \%)$ has been found within the years of 1 to 5 customer of the bank, followed by less than one-year respondents. Which also supported by interview undertaken with respective managers of the banks. Further, the results indicated as most of the respondents are associated with saving account indicating 63\%. The managers of commercial banks response indicated as majorly serving customers those associated with saving account. Since there are few customers with investment accounts the deposits accumulation is high that makes money circulation low. The majority of respondents (64\%) are Bachelor degree and above holders as well as Government/NGO is their source of income. The interview results indicated as our country majority of population is farmers and low saving habits in the country the account holders are civil servants.

Table 2. Correlation matrix between intention and its predictors

\begin{tabular}{|c|c|c|c|c|c|c|c|}
\hline & & INT & AW & RELAD & COMP & CLEX & PTR \\
\hline INT & $\begin{array}{l}\text { Pearson Correlation } \\
\text { Sig. (2-tailed) }\end{array}$ & 1 & & & & & \\
\hline$\overline{\mathrm{AW}}$ & $\begin{array}{l}\text { Pearson Correlation } \\
\text { Sig. (2-tailed) }\end{array}$ & $\begin{array}{l}.213^{* *} \\
.000\end{array}$ & 1 & & & & \\
\hline RELAD & $\begin{array}{l}\text { Pearson Correlation } \\
\text { Sig. (2-tailed) }\end{array}$ & $\begin{array}{l}.235^{* *} \\
.000\end{array}$ & $\begin{array}{l}.109^{*} \\
.032\end{array}$ & 1 & & & \\
\hline$\overline{\mathrm{COMP}}$ & $\begin{array}{l}\text { Pearson Correlation } \\
\text { Sig. (2-tailed) }\end{array}$ & $\begin{array}{l}.282^{* *} \\
.000\end{array}$ & $\begin{array}{l}-.013 \\
.416\end{array}$ & $\begin{array}{l}.703^{* *} \\
.000\end{array}$ & 1 & & \\
\hline$\overline{\text { CLEX }}$ & $\begin{array}{l}\text { Pearson Correlation } \\
\text { Sig. (2-tailed) }\end{array}$ & $\begin{array}{l}-.145 \\
.023\end{array}$ & $\begin{array}{l}-.129^{*} \\
.014\end{array}$ & $\begin{array}{l}-.711^{* *} \\
.000\end{array}$ & $\begin{array}{l}-.712^{* *} \\
.000\end{array}$ & 1 & \\
\hline$\overline{\text { PTR }}$ & $\begin{array}{l}\text { Pearson Correlation } \\
\text { Sig. (2-tailed) }\end{array}$ & $\begin{array}{l}.115^{*} \\
-.025\end{array}$ & $\begin{array}{l}.039 \\
.252\end{array}$ & $\begin{array}{l}-.015 \\
.403\end{array}$ & $\begin{array}{l}.017 \\
.384\end{array}$ & $\begin{array}{l}-.007 \\
.454\end{array}$ & 1 \\
\hline & $\mathrm{N}$ & 178 & 178 & 178 & 178 & 178 & 178 \\
\hline
\end{tabular}

**. Correlation is significant at the 0.01 level (2-tailed).

*. Correlation is significant at the 0.05 level (2-tailed).

As shown in the correlation matrix Table 2, the correlation coefficient value illustrates as all predictors are has small positive relationship and statistically significant correlation with Intention to use the financial products except complexity and perceived trust. The result shows as all variables correlates best with the outcome and so it is likely that all variables best predict customers' intention to use financial products and services. The result is consistence with the study's findings of (Gerrard \& Cunningham, 2003b; Rosly \& Bakar, 2003a; Puschel \& Hernandez, 2010; Teo \& Pok, 2003; Shih \& Fang, 2004; Sharofiddin \& Bin- Yousoff, 2013) which indicated as there is a positive significant relationship between personal awareness level, relative advantage of the products, customers perceived trust of the products as well as its compatibility and complexity with the customers decision to patronize an Islamic bank product.

Additionally, the majority of interview result indicated the banks in Ethiopia plays a major role in awareness creation in relation to both existing and new financial products launched therefore there is no awareness problem. As well as the majority of interviewee indicated since aggressive awareness creation provided for the end user that the financial products and services is not as such complex. This shows as some of the result of correlation matrix opposed with the interview results.

\section{Regression analysis}

The regression analysis was conducted to know by how much the independent variable explains the dependent variable. Before we go to in detail of multiple regression assumption of multivariate normal distribution, independence of errors, and equality of 
variance were first tested. This study involves a relatively large sample of 209 customers and all commercial banks headquarters employees 57) and therefore, the Central Limit Theorem could be applied and hence there is no question on normality of the data. Two major methods were utilized in order to determine the presence of multicollinearity among independent variables in this study. These methodologies involved calculation of both a Tolerance test and Variance Inflation Factor (VIF) (Kleinbaum \& Klein M, 2002). The results of these analyzes are shows as all predictors VIF is below 10 and none of the Tolerance levels is < or equal to .01. Multicollinearity was not a concern with this data set as confirmed by the main effect regression models.

According to (Field, 2009) the acceptable Durbin - Watson range is between 1.5 and 2.5. In this analysis Durbin - Watson values are ranges from 1.823 to 2.133 , which are between the acceptable ranges, show that there was no auto correlation problems in the data used in this research. Thus, the measures selected for assessing independent variables in this study do not reach levels indicate of multicollinearity. Therefore, regression analysis of Predictors and Dependent variables was conducted and the results of the regression analysis are presented as following section.

\section{Adoption of interest free banking}

Here it regressed to know the impact of economic situation, technological change, government policies and cultures have on adoption of Interest free financial products and services. It presented as Table 3 and 4.

Table 3. ANOVA and R square

\begin{tabular}{|c|c|c|c|c|c|}
\hline Model & $\begin{array}{l}\text { Sum of } \\
\text { Squares }\end{array}$ & Df & $\begin{array}{l}\text { Mean } \\
\text { Square }\end{array}$ & $\mathrm{F}$ & Sig. \\
\hline Regression & 56.448 & 3 & 18.816 & \multirow[t]{3}{*}{186.297} & \multirow[t]{3}{*}{0.000} \\
\hline Residual & 5.353 & 53 & 0.101 & & \\
\hline Total & 61.801 & 56 & & & \\
\hline & R Square $=0.807$ & \multicolumn{3}{|c|}{ Adjusted R Square $=0.802$} & \\
\hline
\end{tabular}

Table 4. Regression model result for beta coefficients

\begin{tabular}{lllllll}
\hline Model & \multicolumn{2}{c}{$\begin{array}{c}\text { Unstandardized } \\
\text { Coefficients }\end{array}$} & $\begin{array}{c}\text { Standardized } \\
\text { Coefficients }\end{array}$ & \multirow{2}{*}{ T } & Sig. \\
\cline { 2 - 5 } & B & Std. Error & Beta & & \\
\hline 1 & (Constant) & -0.624 & 0.110 & & -5.671 & 0.000 \\
& TECH & 0.179 & 0.068 & 0.140 & 2.643 & 0.009 \\
& LRB & 0.217 & 0.073 & 0.189 & 2.974 & 0.003 \\
& ECO & 0.678 & 0.106 & 0.477 & 6.368 & 0.000 \\
CUL & 0.192 & 0.058 & 0.181 & 3.323 & 0.001 \\
\hline
\end{tabular}

a. Dependent Variable: ADP

The Table 3 shows impacts of technological advancement, government policies and economic factors explain adoption of financial products in commercial banks in Ethiopia by the value of $\mathrm{R}^{2}$ is .807 and the remining .193 by others variables.

\section{Intention to use}

Here it regressed to know the variation of Awareness, Relative advantage; Compatibility, Complexity, and Trust have on Intention to use. It presented as Table 5 and 6. 
Table 5. ANOVA and R square

\begin{tabular}{|c|c|c|c|c|c|c|}
\hline Model & & Sum of Squares & Df & Mean Square & $\mathbf{F}$ & Sig. \\
\hline \multirow[t]{4}{*}{1} & Regression & 54.375 & 5 & 10.875 & 14.179 & $.000^{\mathrm{b}}$ \\
\hline & Residual & 131.924 & 172 & .767 & & \\
\hline & Total & 186.299 & 177 & & & \\
\hline & & R Square $=0.2304$ & Adjus & Square $=0.222$ & & \\
\hline
\end{tabular}

Table 6. Regression model result for beta coefficients

\begin{tabular}{lllllll}
\hline \multirow{2}{*}{ Model } & \multicolumn{2}{l}{$\begin{array}{l}\text { Unstandardized } \\
\text { Coefficients }\end{array}$} & $\begin{array}{l}\text { Standardized } \\
\text { Coefficients }\end{array}$ & T & Sig. \\
\cline { 2 - 4 } & B & Std. Error & Beta & & \\
\hline $\mathbf{1}$ & (Constant) & 1.130 & .314 & & 3.602 & .000 \\
& AW & .254 & .060 & .244 & 4.179 & .000 \\
& RELAD & .286 & .065 & .280 & 4.389 & .000 \\
& COMP & .268 & .102 & .292 & 2.638 & .000 \\
& CLEX & -.286 & .065 & -.280 & 4.389 & .000 \\
& PTR & -.145 & .049 & -.227 & 2.96 & .000 \\
\hline
\end{tabular}

a. Dependent Variable: INT

The Table 5 shows of customers Awareness, Perceived Advantage, perceived Compatibility, perceived complexity, and perceived trust on intention indicates as the value of $\mathrm{R}^{2}$ is .2304 , which means that All predictors accounts for $23.04 \%$ of the variation in Intention and the value of adjusted $\mathrm{R}^{2}$ is .222 which is .008 or $0.8 \%$ difference from $\mathrm{R}^{2}$ that indicates if the model were derived from the population rather than a sample it would account for approximately $0.8 \%$ less variance in the outcome.

\section{Summary of hypotheses testing}

In this study Linear Regression was used to test the research hypotheses. The Table 7 shows the summarized results of the hypotheses tested.

Table 7. Regression coefficients result

\begin{tabular}{lllllll}
\hline Factors & Beta & T-Values & Sig. & Mean & Std. dev & Decision on Hypothesis \\
\hline AW & +.254 & 4.179 & $.000^{* *}$ & 2.323 & .94819 & Failed to reject H1 \\
RELAD & +.286 & 4.389 & $.000^{* *}$ & 4.821 & .34093 & Failed to reject H2 \\
COMP & +.268 & 2.638 & $.000^{* *}$ & 4.799 & .42746 & Failed to reject H3 \\
CLEX & -.286 & 4.389 & $.000^{* *}$ & 1.833 & .34093 & Failed to reject H4 \\
PTR & -.145 & 2.960 & $.000^{* *}$ & 2.083 & .5420 & Failed to reject H5 \\
TECH & 0.157 & 3.023 & $0.003^{*}$ & 3.285 & 1.1800 & Failed to reject H6 \\
LRB & 0.217 & 2.974 & $0.003^{*}$ & 2.287 & 1.4613 & Failed to reject H7 \\
ECO & 0.678 & 6.368 & $0.000^{*}$ & 4.292 & .62882 & Failed to reject H8 \\
CUL & 0.253 & 6.060 & $0.000^{*}$ & 3.864 & .91762 & Failed to reject H9 \\
\hline
\end{tabular}

*. Statistically significant at the 0.01 level

The Table 7 presents the p-value (0.000) of all variables are found to have a significant effect on Adoption and customers intention towards using Interest free banking at $1 \%$ significance level. Therefore, the all null hypothesis is failed to reject. Specifically, the customers' Awareness of using Interest free banking positively significantly affects the intention of customers towards using it. This is in line with the proposition of Thambiah, etal., 2011b, which is also in line with the findings of (Teo \& 
Pok, 2003; Sharofiddin \& Bin- Yousoff, 2013) that indicate as awareness have a significant impact on the use of banking product and services.

The mean of variable is 2.323 which indicates as customers are not properly know the current service offered by the bank, the product and services are difficult to differentiate from conventional, not better marketing their products and services to the public and not believe as IFB is offered to both Muslim and non-Muslim. Additionally, the interview result suggests as the newness of IFB in Ethiopia will take time for the public to embrace and needs a large awareness creation activity from the bank even if the bank promoting it via TV, Radio, Newspaper, Magazines.

Also, the Perceived relative advantage of using Interest free banking positively affects the intention of customers towards using it. This result is in line with those of (Taylor \& Todd, 1995b; Teo \& Pok, 2003; Shih \& Fang, 2004; Puschel \& Hernandez, 2010; Tan \& Teo, 2000; To, Liao, Chiang, Shih, \& Chang, 2008). Hence, these are the main dimensions that can determine the superiority of either the banks from the customers $^{\text {ee }}$ perspective. The mean of variable is 4.8213 which show that as the respondents perceived that getting products and services via separate windows are proper for activity, they deal with than conventional one and beneficial as financing is based on shares profit or loss made out of it than conventional one.

Similarly, the Perceived compatibility of using Interest free banking positively significantly affects the attitude of customers towards using it. This is in accordance with the findings of (Tan \& Teo, 2000; To, Liao, Chiang, Shih, \& Chang, 2008; Puschel \& Hernandez, 2010). Nevertheless, it contradicts with the findings of (Teo \& Pok, 2003; Shih \& Fang, 2004). The mean of the variable is 4.7990 which indicate as respondents perceived that the products and services provided via separate windows can fit with their banking needs than conventional as it depends on sharia, and good complementary product that fulfill their belief and ways of life.

In the same way, the complexity of an innovation affects how well customers view it and develops a certain attitude. The result shows as perceived complexity negatively influences the attitude of Customers towards Interest free banking. This is similar to the findings of (Tan \& Teo, 2000), while it contradicts with the findings of (Shih \& Fang, 2004; Taylor \& Todd, 1995b). The mean of the variables is 1.833 which indicates as understanding and using terms and concepts of Interest free banking do not requires a lot of mental effort, and the different name the banks use for these financial products and services from the conventional simple to understand and use. The name Interest free banking communicates and gives enough confidence to the respondents about its usage friendliness, so in turn, most of the respondents indicate as they products is easy to understand and use.

Further, the Perceived Trust of using Interest free banking negatively significantly affects the attitude of customers towards usage of it. This is consistent with (Sharofiddin $\&$ Bin- Yousoff, 2013) that conclude as trust have negative significant relationship with the adoption of banking product and services while, contradict with the findings from (Palvia, 2009) which indicates trust has a positive significant effect on customers ${ }^{\text {ee }}$ attitude to use innovation. The mean value of variables is 2.083 which indicate the customers are not clear and trust the bank regarding IFB transaction. In addition the information from those are on managerial position in CBE was explained as they follow NBE directive $51 / 2011$ that enforces to segregate the capital of IFB from the conventional bank, while, Some of frontline staffs of the bank pinpoint that as the IFB amount are not as such proper segregated from conventional bank in cash. 
Furthermore, the p-value of Technological advancement, legal and regulatory barriers, Economic factors and societal cultures as the independent variables and Adoption as the dependent variable is 0.000 . This means the probability of variation in the dependent variable to occur by chance (not to be affected by the explained independent variables) is 0.000 . Therefore, the null hypothesis of $6,7,8$ and 9 are accepted.

\section{CONCLUSIONS AND RECOMMENDATIONS}

\section{Conclusions}

There are different financial products and services provided and launched by commercial banks in Ethiopia. Interest free banking is the one. Based on the study results from banks adoption of financial products and services perspectives demonstrated as dynamics technology in the business environment affects the banks to adopt Interest free financial products and services, the existing legal and regulatory barriers also prevents banks to adopt, the economic factors like lack of income, irregularity of income, unemployment affect the activity rate of society engaging in any type of financial service that prevents banks to adopt. Furthermore, majority of people keeping their money at home as the result of lack of education, trust and religions that signifying low saving cultures in the country. Furthermore, the study revealed as Interest free financial products and services are not properly used by the customers as the result of less perceived relative advantage of owing it by the customers, low level of customers awareness towards the existence of the financial products and services, the complexity looking of Interest free financial products and services to the customers, considering as using Interest free financial products and services is not compatible for them, less Perceived Trust of the banks.

\section{Recommendations}

This study gives hindsight for promoters to aware the prospective hindrance on the existing and newly launched Interest free financial products and services; customer's level of perception of the product, which should subsequently allow them to formulate and develop policies and regulations, to make an adjustment to the existing banking industry in Ethiopia and to establish the necessary strategies to attract individual customers and retain the existing, technology needed must be available and government support on financing structure.

The findings of the current study have significant contributions to the body of knowledge in that the study add value to the banking industry on testing the financial products in banking industry in context of Ethiopia that is lack in the literatures. Furthermore, the study extends and tests the decomposed theory of planned behavior in another context and another area i.e. Interest free financial products and services adoption and usage.

\section{REFERENCES}

Ahmad, K. (2000). Islamic finance and banking: the challenge and Prospects. Review of Islamic Economics, 9, 57-82.

Anol, B. (2012). Social science research: Principles, methods, and practices. Texbooks Collection 3. Available at: https://scholarcommons.usf.edu/oa_textbooks/3/

B.S., C., \& Ming-Hua, L. (2007). Islamic Banking: Interest-Free or Interest based? Pasific-Basin Finance Journal, 17(1), 125-144 
Brown, T. A. (2015). Confirmatory factor analysis for applied research. New York: Guilford publications.

Creswell, J. (2013). Qualitative inquiry and research design: Five different approaches. Thousand Oaks, CA: Sage Publishing.

DeCoster, J. (1998). Overview of Factor Analysis. Available at: . http://www.stathelp.com/notes.html

Field, A. (2009). Discovering Statistics Using SPSS. Thousand Oaks, CA: Sage Publishing

Gait, A. \&. (2008). An empirical survey of individual consumer, business firm and financial institution attitudes towards Islamic methods of finance. International Journal of Social Economics, 35(11), 783-808.

Gait, A., \& Worthington, A. (2008). An empirical survey of individual consumer, business firm and financial institution attitudes towards Islamic methods of finance. International Journal of Social Economics, 35(11), 783-808.

George, D., \& Mallery, P. (2003). SPSS for Windows step by step: A simple guide and reference. 11.0. Available at: https://wps.ablongman.com/wps/media/objects/ 385/394732/george4answers.pdf

Gerrard, P., \& Cunningham, J. (2003b). The diffusion of internet banking among Singapore consumers. International Journal of Bank Marketing, 21(1), 16-28.

Hair, J. B., \& R.E., A. (2006). Multivariate Data Analysis: A Global Perspective . (7, Ed.) Pearson Education Inc.

Holliday, K. (1996). Keeping close to the customer. International Journal of Bank Marketing, 28, 14-19.

Karbhari, Y., Naser, K., \& Shahin, Z. (2004). Problems and Challenges Facing the Islamic Banking system in the west: the case of UK. Thunderbird International Business Review, 46(5), 521-543.

Kebede, D. A. (2015). Factors Affecting Customers to Use Interest Free Banking in Ethiopia. (Unpublished project work).

Khan, M., \& Bhatti, M. (2008b). Islamic banking and finance: on its way to globalization. Managerial finance, 34(10), 708-725.

Kleinbaum, D., \& Klein M. (2002). Logistic Regressions: A self-learning text. Berlin Springer.

Muhumed, M. (2012). Islamic Banking: Prospects, Opportunities and Challenges in Ethiopia (unpublished project paper).

Neuman, W. L., \& Kreuger, L. (2003). Social work research methods: Qualitative and quantitative approaches. Boston: Allyn and Bacon.

Owusu-Frimpong, N. (199). Patronage behavior of Ghanaian bank customers. International Journal of Bank Marketing, 17(7), 335-341.

Palvia, P. (2009). The role of trust in e-commerce relational exchange: A unified model. Information \& Management, 46(4), 213-220.

Puschel, J. M., \& Hernandez, J. M. (2010). Mobile banking: proposition of an integrated adoption intention framework. International Journal of Bank Marketing, 28, 389409.

Rosly, S., \& Bakar, M. (2003a). Performance of Islamic and mainstream banks in Malaysia. International Journal of Social Economics, 30(12), 1249-1265.

Saidi, A. (2007). Relationships between ethical and Islamic banking systems and its business management implications,. South Africa Journal of Business Management, 1, 43-49. 
Sankaramuthukumar, S., \& Devamohan, A. (2008). The potentiality of Islamic banking in Ethiopia, a research paper to be presented at the sixth international conference on the Ethiopian economy.

Shaik Abdul Majeeb, P. (2014). Role and Progress of Islamic Banking in India, Ethiopia and Rest of the World - An Analysis. European Journal of Business and Management, 6(17).

Sharofiddin, A., \& Bin- Yousoff, W. S. (2013). The challenges of conventional banking practice and prospects of introducing an Islamic bank to Tajikistan. 9th International Conference on Islamic Economics and Finance: Growth, Equity and Stability. An Islamic Perspective.

Shih, Y., \& Fang, K. (2004). The use of a decomposed theory of planned behavior to study Internet banking in Taiwan. Internet Research, 14(3), 213-223.

Tan, M., \& Teo, T. (2000). Factors influencing the adoption of Internet banking. Journal of the Association for Information Sciences, 1, 1-42.

Taylor, S., \& Todd, P. (1995b). Decomposition and crossover effects in the theory of planned behavior: A study of consumer adoption intentions. International Journal of Research in Marketing, 12, 137-155.

Teo, T., \& Pok, S. (2003). Adoption of WAP- enabled mobile phones among Internet users. Omega - The International Journal of Management Science, 31(6), 483498.

Thambiah, S., Eze, U. C., Santhapparaj, A. J., \& Arumugam, K. (2011b). Customers ${ }^{\text {ee }}$ Perception on Islamic Retail Banking: A Comparative Analysis between the Urban and Rural Regions of Malaysia. International Journal of Business and Management, 6(1), 187- 198.

To, P., Liao, C., Chiang, C., Shih, M., \& Chang, C. (2008). An empirical investigation of the factors affecting the adoption of instant messaging in organizations. Computer Standards and Interfaces, 30, 148-156.

(C) 2020 by the authors. Licensee JPPD, Indonesia. This article is an open access article distributed under the terms and conditions of the Creative Commons Attribution (CC BY) license (http://creativecommons.org/licenses/by/4.0/). 